\title{
Oil and Grease Removal from Industrial Wastewater Using New Utility Approach
}

\author{
H. S. Abd El-Gawad \\ Head of Organic Chemistry Department, Central Laboratory for Environmental Quality Monitoring (CLEQM), \\ National Water Research Center (NWRC), P.O. Box 13621/6, El-Kanater, Qalubiya, Cairo, Egypt
}

Correspondence should be addressed to H. S. Abd El-Gawad; htamh@hotmail.com

Received 5 January 2014; Accepted 12 May 2014; Published 8 July 2014

Academic Editor: Vincenzo Belgiorno

Copyright (C) 2014 H. S. Abd El-Gawad. This is an open access article distributed under the Creative Commons Attribution License, which permits unrestricted use, distribution, and reproduction in any medium, provided the original work is properly cited.

The present study is an attempt to investigate oil and grease pollution that may pollute fresh water and influence aquatic environment. Then removal of oil and grease from manufacturing wastewater befall essential but common techniques not enough. Enzyme and adsorption units representing major developed new laboratory were selected to assess the water quality and humiliation prospective of oil and grease from wastewater. Several components and environmental variables that were dissolved oxygen, bacteriology measure, flow rate and adsorption material amount studied to assess the removal performance of oil and grease. The results elucidated significant variations among different tests which influenced microbial necessary role of oxidation declining develop biological treatment process reached to $72 \%$. The study stressed out natural material (zeolite) that enhanced organic reduction under optimal conditions. These conditions were closer spacing and high length of adsorbing unit that led to increase oil and grease contact period with adsorbent and added to increase performance removal reached to $99 \%$.

\section{Introduction}

Organic toxic waste (oil and grease $(\mathrm{O} \& \mathrm{G})$ ) causes ecology damages for aquatic organisms [1], plant, animal, and equally, mutagenic and carcinogenic for human being [2]. They discharge from different sources to form a layer on water surface that decreases dissolved oxygen. O\&G layer reduces biological activity of treatment process where oil film formation around microbes in suspended matter and water. This lead to decrease dissolved oxygen levels in the water. Then oxygen molecules are difficulty to be oxidative for microbial on hydrocarbon molecules and cause ecology damages to water bodies $[3,4]$.

The conventional techniques remove oil and grease using skimming tanks and oil and grease traps in treatment plants but the main disadvantage of these methods is their low efficiency of removal.

The remaining oil causes clogging of pipes in treatment units that need cleaning and sometimes replacement of pipes. This lead to increase maintenance and inspection cost [5]. Recently, alternative uses of biochemical route (enzymes and lipases) have potentially gained more attention due to their clean and friendly application and to overcome limitation [6]. Microbial activity plays significant role in performance, strength purification process, and elimination of pretreatment process in wastewater treatment plant depending on enzyme costs [7]. Environmental studies described prevention of fat blockage or filming in waste systems before discharging wastewater into sewage system. These studies investigated new approach to degrade organic matter with commercial mixture (lipase enzymes) that cleans holding tanks, septic tanks, grease traps, and other systems [8].

Lipases constitute a large category of ubiquitous enzymes that are water soluble. They hydrolyze ester bonds of water in soluble substrates and act at the interface between a substrate phase and an aqueous phase [9]. They have low production cost, play ecological significance in oxidation reduction, and can reflect organic matter circulation for wastewater treatment [10]. They do not require purification and enzyme activity serve as biological indicator for sediment to reflect eutrophication level of water resources [11]. These characteristics led to increase enzyme production technology and 
search new microorganisms with a diverse ability to produce enzymes. Lipases find applications in detergent formulation, textile, paper industries, bio-diesel, and pretreatment of lipidrich wastewaters. Biotechnological processes as microbial lipases are the most attractive that their properties such as flexibility and ease of mass production can apply [12]. The application of Pseudomonas spp. strains' activities catalyzes the increasing hydrolysis of $\mathrm{O} \& \mathrm{G}$ waste; it can be considered as pretreatment to decrease organic matter concentration, color, and suspended solids $[13,14]$.

In view of water pollutants, they are becoming more complex and multi pollutants simultaneous removal is paid more and more attention to be removed. Recent composite materials such as aluminum oxide, nano particles, amorphous zeolite and laterite adsorbents are used to treat complex wastewater that have high adsorption capacities [15].

With these points in view, the present research studies new approach to degrade toxic waste (oil and grease) form industrial wastewater. The work presented lipase hydrolysis stage using Pseudomonas strains as a producer of lipase and assess their degradation capabilities. This approach included enzyme unit coupling with adsorbent materials as efficient method to complete removal. Adsorption technique uses zeolite (laterite and amorphous materials) as easily and cheaply available adsorbent.

\section{Materials and Methods}

\subsection{Environmental Sampling Program}

2.1.1. Study Area. Wastewater samples for chemical analysis were collected directly from main source of Kafr El-Zayat industrial area while the sludge is collected from El-Rahway drain along Rosetta branch (Figure 1). Wastewater samples were collected from oil and detergent industry that produced food oil products which include fat replacement and cooking oil. The industry also produces oil products for application in dairy products and coloring and as food ingredients.

2.1.2. Water Samples Collection. Water samples were collected at $60 \mathrm{~cm}$ depth from investigated sites; using plastic bottles (1 liter capacity) for physicochemical measurements and oxygen demanding variables included total organic carbon (TOC), chemical oxygen demand (COD) and biological oxygen demand (BOD) parameters that stored in refrigerator at $4^{\circ} \mathrm{C}$ prior to analysis [16]. One-liter glass bottles were also filled with water samples for oil and grease measurement in $(1 \mathrm{~m}$ $\times 1 \mathrm{~m}$ ) area. Measurements were always carried out during the sampling day in order to keep minimum fluctuations of physical and chemical parameters that caused by temperature differences.

Sludge. The sludge is collected from El-Rahway drain along Rosetta branch (Figure 1). The raw wastewater and sludge from oil and detergent industry and El-Rahway drain were collected as the subjects for this study. These samples were collected using 10-liter containers at temperature range $4 \pm$ $1^{\circ} \mathrm{C}$ for preservation.

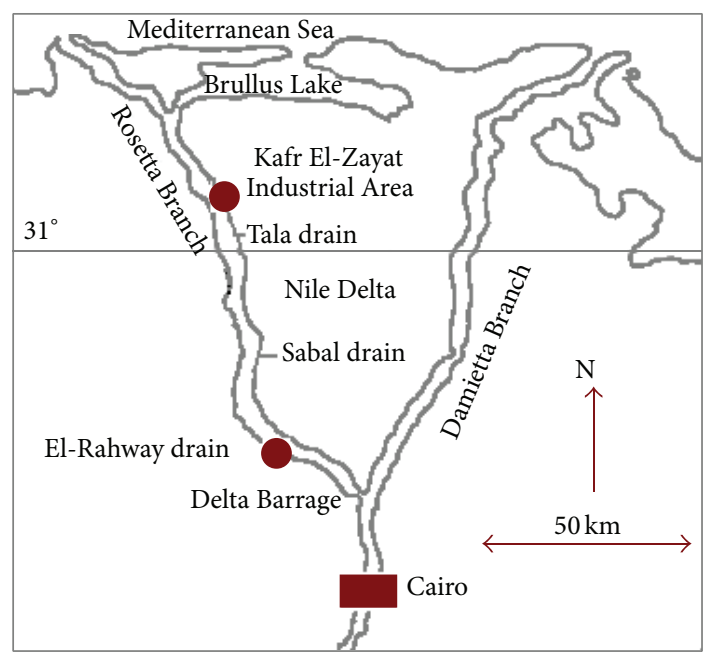

FIGURE 1: Sampling sites.

2.1.3. Field Measurement. In situ field measurements including temperature, D.O., T.D.S, $\mathrm{pH}$, and electrical conductivity (E.C) were measured using multi-probe system, model Hydrolab-Surveyor.

2.1.4. Laboratory Measurements. The determination of important water quality parameters that are playing main role in the human health was carried out according to standard techniques [16]. In lab, total dissolved solids (T.D.S) using gravimetric method, total suspended solid using Huch DR2010 while carbonate and bicarbonate using titration method (0.02 NH2SO4-methods 2310B and 2320B) were determined.

Many organic measurements are selected to represent gross fraction of organic matter that include biological oxygen demand (BOD) using BOD fast respirometry system model TS $606 / 2$ at $20 \pm 1^{\circ} \mathrm{C}$ incubation in a thermostatic incubator chamber model WTW (Method 5210B, 5210D), chemical oxygen demand (COD) using Huch DR-2010 (method 5220D), total organic carbon (TOC) using a multiN/C-3100 (method 5310C) and the measurements of oil and grease were performed using partition-gravimetric method (method 5520B).

On other hand, counting total coliform (T.C) was recorded as colony forming unit $(\mathrm{CFU} / 100 \mathrm{~mL})$ using the membrane filter technique according to standard methods (number 9222B and 9222D).

2.2. Treatment. The experiment consisted of two divisions that were laboratory experimental unit (LEU) and laboratory scale column (LSC). The experiment LEU use originally stock (Pseudomonas strains lipases) in microbial process that obtained from Sigma while laboratory scale column use adsorbent zeolite column (laterite and amorphous material) as shown in Figures 2 and 3. LEU simply involves wastewater and mixed culture of Pseudomonas strains lipases together under aerobic condition. Wastewater is the incoming sewage and sludge recycles with rich cultural of microbial enzyme. 


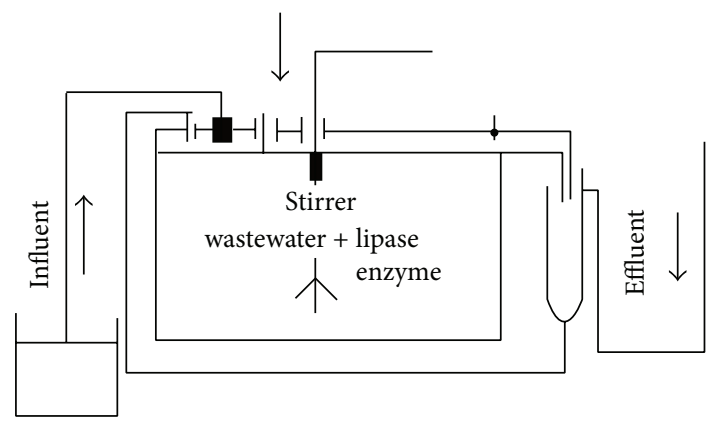

FIGURE 2: Schematic diagrams of laboratory experimental unit.

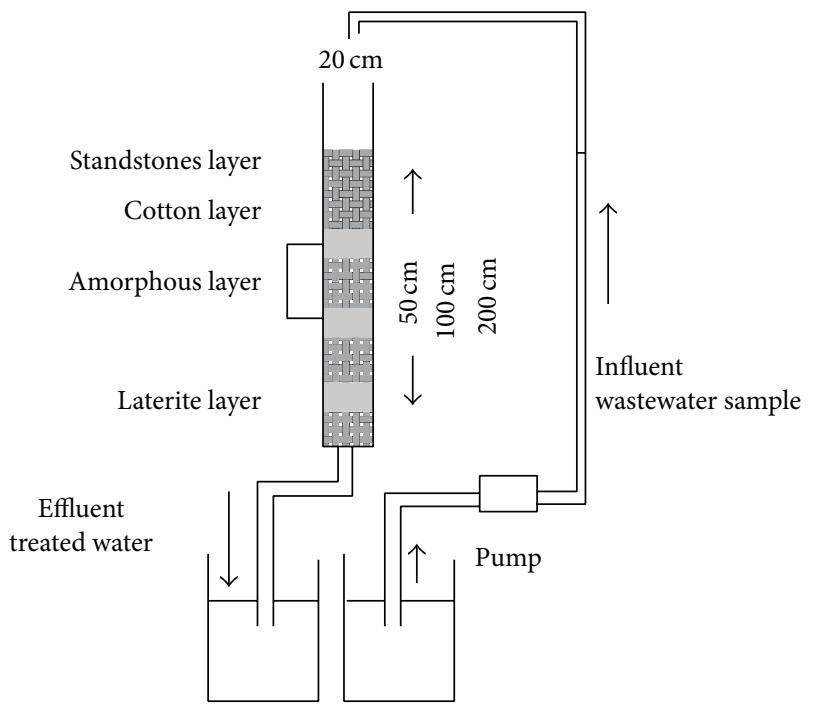

FIGURE 3: Schematic diagrams of laboratory zeolite column.

2.2.1. Experimental Setup. Characteristics of wastewater and sludge are shown in Table 1. Acclimatization is a process for microorganisms in the sludge to be adapting to renew wastewater environment and to maintain the performance of different environmental conditions. Lipases application require lipase activity, their stability at alkaline $\mathrm{pH}$, effect of temperatures above $40 \pm 1^{\circ} \mathrm{C}$ and compatibility with different pollutants to remove $\mathrm{O} \& \mathrm{G}$.

Acclimatization is carried out using a mixture of activated sludge and wastewater $(3: 1 \mathrm{v} / \mathrm{v})$ for five days. Every acclimatization process used three-liter stirred tank with a 6-blade up-pumping 450-pitched blade impeller at $200 \mathrm{rpm}$.

2.2.2. Lipase Enzyme. The potential lipase enzyme (LE) treatment process of oily wastewater was carried out to study the aeration and sludge concentrations effect as shown in Table 2. All runs are carried out in a three-liter cylinder tank and stirred with a 4-blade up-pumping 600-pitched blade impeller at $400 \mathrm{rpm}$. To provide aeration, an air pump was utilized to provide different rates of air supply.

Serial experiments were conducted at the room temperature to investigate the influence of aeration and sludge volume for removing organic pollution (oil and grease and COD)
TABLE 1: Characteristic of wastewater and sludge.

\begin{tabular}{lccc}
\hline Parameter & Unit & Industrial wastewater & Sludge \\
\hline Temp. & ${ }^{\circ} \mathrm{C}$ & 18.9 & 20.1 \\
pH & - & 8.4 & 8.81 \\
EC & $\mathrm{mmhos} / \mathrm{cm}$ & 2.34 & 3.14 \\
TSS & $\mathrm{mg} / \mathrm{L}$ & 132 & 345 \\
TDS & $\mathrm{mg} / \mathrm{L}$ & 1503 & 2041 \\
D.O & $\mathrm{mg} / \mathrm{L}$ & 3.2 & 1.35 \\
COD & $\mathrm{mg} / \mathrm{L}$ & 572 & 3100 \\
BOD & $\mathrm{mg} / \mathrm{L}$ & 388 & 400 \\
TOC & $\mathrm{mg} / \mathrm{L}$ & 60.1 & 300 \\
Oil and grease & $\mathrm{mg} / \mathrm{L}$ & 292.4 & 0.005 \\
Total coliform & $\mathrm{CFU} / 100 \mathrm{~mL}$ & $645 \times 10^{3}$ & $245 \times 10^{7}$ \\
\hline
\end{tabular}

TABLE 2: Experimental design of aeration and sludge effects.

\begin{tabular}{lcl}
\hline Lipase enzyme & Sludge & Aeration \\
\hline & Normal sludge & Low aeration-1 L/min, \\
& & D.O $=4 \mathrm{mg} / \mathrm{L}$ \\
Rich of & Dilute sludge & Medium aeration-2 L/min, \\
Pseudomonas & $1: 5$ & D.O $=6 \mathrm{mg} / \mathrm{L}$ \\
strains & Dilute sludge & High aeration-3 $\mathrm{L} / \mathrm{min}$, \\
& $1: 10$ & D.O $=8 \mathrm{mg} / \mathrm{L}$ \\
\hline
\end{tabular}

TABLE 3: Experimental design.

\begin{tabular}{lcc}
\hline Zeolite dosage & Length & Flow rate \\
\hline $50 \mathrm{gm}$ & $50 \mathrm{~cm} \times 20 \mathrm{~cm}$ & Low \\
$50 \mathrm{gm}$ & $100 \mathrm{~cm} \times 20 \mathrm{~cm}$ & Medium \\
$50 \mathrm{gm}$ & $200 \mathrm{~cm} \times 20 \mathrm{~cm}$ & High \\
\hline
\end{tabular}

from collected water samples using laboratory experimental unit (LEU) within fixed time (6 hours) (Figure 2). Total volume of $100 \mathrm{~mL}$ water sample (influent) was pumped in the up flow mode from the vessel into LEU by using a Master flex peristaltic pump. Treated samples were collected within fixed time -6 hours and analyzed for organic matter to check the performance treatment.

2.2.3. Zeolite Adsorbent. The potential zeolite adsorbent (ZA) treatment process for oily wastewater was carried out to study the time and the flow rate effects at different length (50, 100 , and $200 \mathrm{~cm} \times 20 \mathrm{~cm}$ ) at fixed width plastic pipe that are considered to estimate O\&G reduction as shown in Table 3. Serial experiments were conducted at room temperature to investigate the influence of time, dosage and remove organic pollution (oil and grease and COD) from wastewater samples using laboratory scale column (LSC) (Figure 3).

Total volume of $100 \mathrm{~mL}$ water sample (influent) was pumped to the up flow mode from the vessel into LSC by using a Master flex peristaltic pump. Treated samples were collected at various time intervals and analyzed for COD and oil and grease to check the performance treatment. 


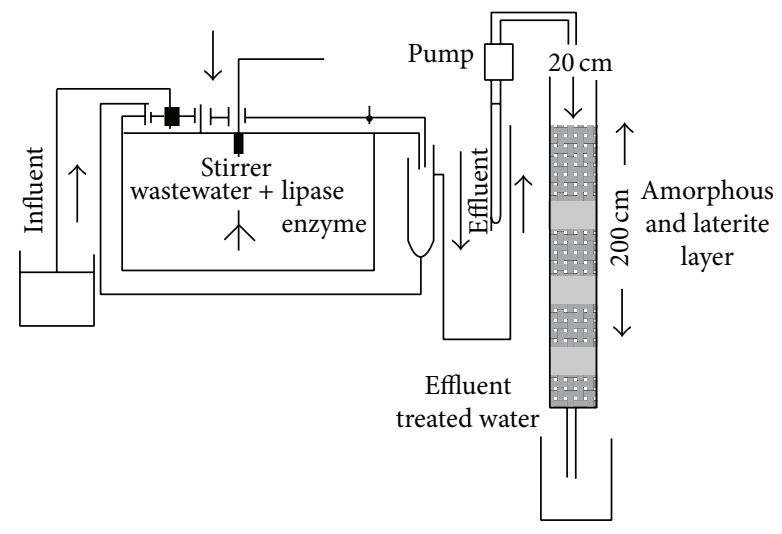

Figure 4: Diagram of LEU and LZC.

2.2.4. Purification of Oil and Grease Waste. Experiment was carried out to determine optimum treatment process and disposal management procedure and avoid industrial risk of oil and grease waste. Laboratory experimental unit (LEU) is simply designed as biotechnology to reduce organic load coupling with a laboratory zeolite column (LZC) to ensure the efficiency of removal organic waste (Figure 4).

\section{Results and Discussion}

Large quantity of enzymatic stock was spread over sludge and wastewaters in LEU. The common bacteria and lipases are important that thousands of lipase units are produced from culture medium [17]. They showed activity among removal of organic pollutants. Bacterial lipases are greatly influenced by nutritional and physicochemical factors, such as temperature, $\mathrm{pH}$, nitrogen, carbon sources, presence of lipids, inorganic salts, and dissolved oxygen concentration [17].

3.1. Enzymatic Profile for Organic Waste Degradation. Bacillus genus showed less activity at high temperatures but its optimal activity and thermal stability is up to $50^{\circ} \mathrm{C}$. The thermal resistance of lipases from Bacillus has already been described [18]. In general, bacterial lipases have optimal activity at neutral or alkaline $\mathrm{pH}$ [4] and lipases from Bacillus species are active over $\mathrm{pH}$ range $(\mathrm{pH}$ 3-12) [19] and our findings indicated that lipase extracts produced by Bacillus species often presented more than that one of optimal $\mathrm{pH}$ values.

Therefore, all experimental steps were conducted to determine the optimum aeration and sludge volume within fixed time ( 6 hours), room temperature and $\mathrm{pH}$ of wastewater sample as shown in (Figure 2). Rich lipase (cell suspension) was conducted at normal sludge, 1:5 and 1:10 diluted sludge. Then, potential enzyme lipase activity was verified and was applied to degrade organic waste differently [11].

Figure 5 clarified COD and O\&G concentrations at different sludge volume that showed the optimum normal sludge volume (COD-60\% and O\&G-50\%). While diluted sludge reached to volume 1:5 (COD-50\% and O\&G-40\%) was more

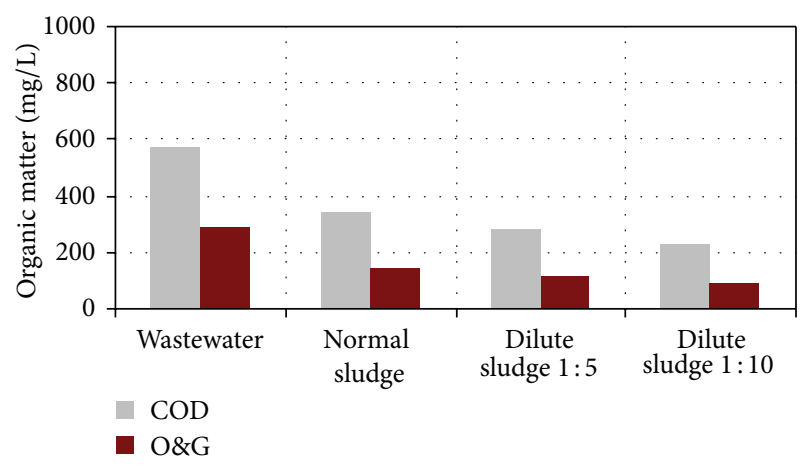

FIGURE 5: Effect of sludge volume on organic matter removal.

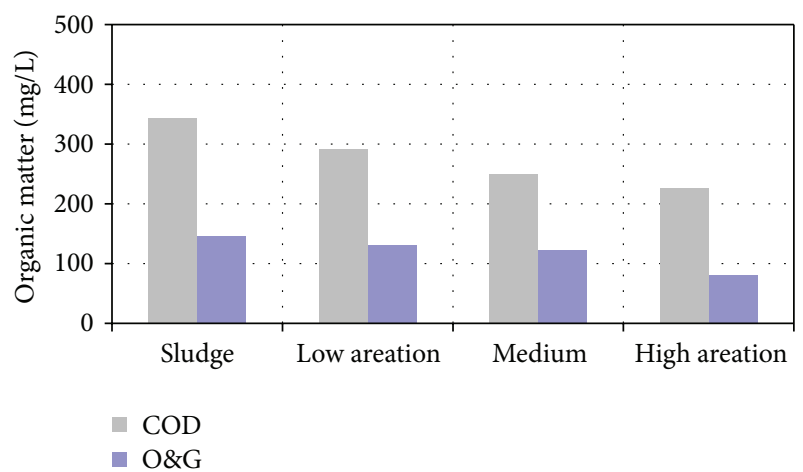

FIGURE 6: Effect of aeration on organic matter removal.

useful for organic degradation than diluted sludge reached to volume than 1:10 (COD-40\% and O\&G-30\%).

On other hand, Figure 6 showed potentially advantageous for biological method development to attack O\&G with normal sludge at low, medium, and high aeration $(10 \%$, $15 \%$, and $20 \%$ reached D.O to $4 \mathrm{mg} / \mathrm{L}, 6 \mathrm{mg} / \mathrm{L}$, and $8 \mathrm{mg} / \mathrm{L}$ ), respectively. The choice of a stable enzyme like lipase is an important aspect for sludge treatment which it was an active phase of growth. Its action required time to complete degradation of organic matter reached to COD-15\%, 27\%, and $33 \%$ at the same conditions for pretreatment plants of industrial wastewater [20].

3.2. Zeolite Evaluation for Oil and Grease Removal. The experiment was conducted in various steps by varying flow rates and times as shown in Table 3 . The samples were collected and analyzed to determine oil and grease concentration and evaluate oil removal efficiency in the laboratory. The results obtained in various experiments were demonstrated in (Figure 7).

It was observed that, oil removal efficiency is decreased under low flow rate and low length conditions which adsorption process depends on time's contact and increase spacing between zeolite spacing. In medium flow rate, efficiency of removal slightly increased. However, an efficiency of $67 \%$ could be seen for slower flow rate and more column length and it was comparable with the efficiency achieved in zeolite dosage. But in high flow rate, the maximum efficiency 


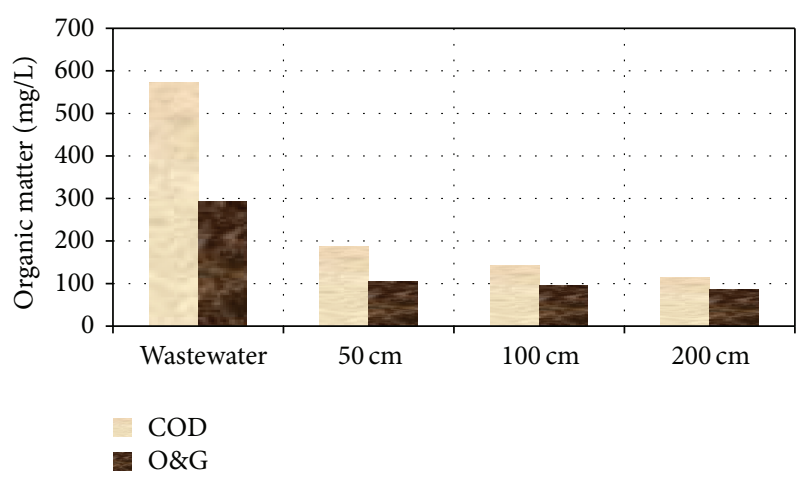

FIGURE 7: Effect of flow rate on organic matter removal.

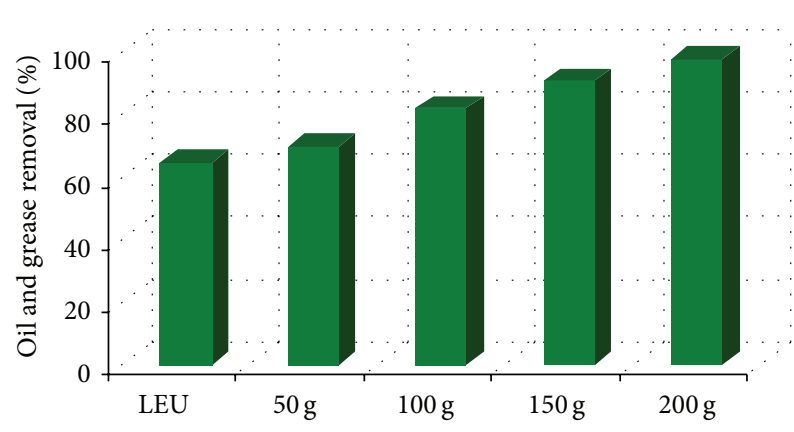

Figure 8: Performance oil and grease removal \%.

reached to $80 \%$, which was comparable with the efficiency achieved for $200 \mathrm{~cm}$ for column length.

Also, it was observed that, as the length of column increased, oil removal efficiency increased and oil concentration decreased. Thus, with more time of movement and more time of contact, the removal efficiency increased. Figure 7 showed the variation of oil removal efficiency and oil concentrations at different time of column length.

3.3. Advanced Purification for Oil and Grease Waste. Laboratory experimental unit (LEU) conducted with laboratory zeolite column (LZC) as shown in (Figure 3). They coupled to complete organic load reduction and ensure the efficiency organic waste removal was achieved. It used as disposal management procedure to decrease industrial risk of oil and grease waste. The experiment was carried out under optimum treatment process: normal sludge, high aeration while LZC: $200 \mathrm{~cm}$ length, mixture of amorphous and laterite zeolite at high flow rate, and different zeolite dosage $(50,100,150$, and $200 \mathrm{~g}$ ).

Even high flow rate condition, efficiency still remained high reached to $91-98 \%$ at 150 and $200 \mathrm{~g}$. Figure 4 showed various oil removal efficiencies in different experiments. Also, it was observed that, as column length increased, organic load removal increased and O\&G concentration decreased. Thus, more time of movement led to more time of contact; the removal efficiency of organic waste increased as shown in (Figures 7 and 8 ).
Figure 8 illustrated the variation of $O \& G$ reduction and oil concentrations at different intervals of zeolite dosage and high LZC length unit. Further, it was also observed that in all four stages, the efficiency increased with the LZC unit's length increased. Based on the results obtained in the different experiments, it is quite that laterite is a powerful adsorbing medium. For closer spacing and slower flow rates, the contact period with adsorbent increased and thus efficiency increased. In addition, as the length of LZC unit increased efficiency also increased. Thus optimum results may be obtained for slower flow rates, closer spacing, and higher LZC unit length. Since laterite is cheaply and easily available, expenses and maintenance incurred are very low as compared to other systems [15].

\section{Conclusion}

Wastewater characteristics are depending on wastewater source that may increase and becoming more toxic in recent times. The concentrations of oil and grease in wastewater streams have been observed to increase adverse effects on the ecology. This results from the increasing oil and grease use, high-demanded oil processed foods, establishment, expansion of oil mills and refineries worldwide, as well as indiscriminate discharge of oil and grease into the water drains, domestically and industrially.

This study reported the applications, efficiencies, and challenges of oil and grease wastewater treatment from industrial wastewater and municipal water stream. The results showed that the concentrations of oil and grease discharged into the ecosystem lead to increase environmental impact. The desired development for effective removal of oil and grease is discussed as emerging pollutants. Lipase and adsorbent material zeolite (mixture of laterite and amorphous) were selected to eliminate $O \& G$ concentration from industrial wastewater.

\section{Recommendations}

The research is clearly that necessary performance of treatment is needed for water reuse and suitable purposes.

(i) Study effect of oil and grease on physiological stress of fish in aquatic environment that may affect the immunology and progeny of species and it may be reduced the total population after a certain period.

(ii) Apply this method in the vehicle service stations in simple method and may be adopted as pretreatment unit in biological treatment plants for industrial wastewater.

(iii) Investigate performance of zeolite adsorbent for potential wastewater recycle in industrial area.

\section{Conflict of Interests}

The author declares that there is no conflict of interests regarding the publication of this paper. 


\section{Acknowledgments}

This research has been supported by the National Water Research Center (Cairo). The author is most grateful to the laboratory staff of various departments of Central Laboratory for Environmental Quality Monitoring.

\section{References}

[1] M. S. Islam, M. Saiful, M. Hossain, M. Sikder, M. Morshed, and M. Hossain, "Acute toxicity of the mixtures of grease and engine wash oil on fish, pangasius sutch, under laboratory condition," International Journal Life Science, Biotechnology and Pharmacology Research, vol. 2, no. 1, pp. 306-317, 2013.

[2] W. U. Lan, G. E. Gang, and W. A. N. Jinbao, "Biodegradation of oil wastewater by free and immobilized Yarrowia lipolytica W29," Journal of Environmental Sciences, vol. 21, no. 2, pp. 237242, 2009.

[3] T. J. Alade, A. M. Suleyman, M. L. Abdul Karim, and M. Z. Alam, "Removal of oil and grease as Emerging Pollutants of Concern (EPC) in wastewater stream," IIUM Engineering Journal, vol. 12, no. 4, pp. 161-169, 2011.

[4] S. Facchin, P. D. D. Alves, S. F. de Faria, M. B. Tatiana, M. N. V. Júnia, and K. Evanguedes, "Biodiversity and secretion of enzymes with potential utility in wastewater treatment," Journal of Ecology, vol. 3, no. 1, pp. 34-47, 2013.

[5] S. A. Mueller, B. R. Kim, J. E. Anderson, A. Gaslightwala, M. J. Szafranski, and W. A. Gaines, "Removal of oil and grease and chemical oxygen demand from oily automotive wastewater by adsorption after chemical de-emulsification," Practice Periodical of Hazardous, Toxic, and Radioactive Waste Management, vol. 7, no. 3, pp. 156-162, 2003.

[6] M. C. M. R. Leal, D. M. G. Freire, M. C. Cammarota, and G. L. Sant'Anna Jr., "Effect of enzymatic hydrolysis on anaerobic treatment of dairy wastewater," Process Biochemistry, vol. 41, no. 5, pp. 1173-1178, 2006.

[7] D. Alberton, D. A. Mitchell, J. Cordova, P. Peralta-Zamora, and N. Krieger, "Production of a fermented solid containing lipases of Rhizopus microsporus and its application in the prehydrolysis of a high-fat dairy wastewater," Food Technology and Biotechnology, vol. 48, no. 1, pp. 28-35, 2010.

[8] Environmental Oasis, "WW07P-Grease removal and food processing," 2012, http://www.oasisenviro.co.uk/ww07pproductinfo.html.

[9] R. Bussamara, A. M. Fuentefria, E. S. D. Oliveira et al., "Isolation of a lipase-secreting yeast for enzyme production in a pilotplant scale batch fermentation," Bioresource Technology, vol. 101, no. 1, pp. 268-275, 2010.

[10] E. Rigo, R. E. Rigoni, P. Lodea, D. D. Oliveira, D. M. G. Freire, and M. D. Luccio, "Application of different lipases as pretreatment in anaerobic treatment of wastewater," Environmental Engineering Science, vol. 25, no. 9, pp. 1243-1248, 2008.

[11] Y. Zhang, B. Cui, S. Wang et al., "Relation between enzyme activity of sediments and lake eutrophication in grass-type lakes in North China," Clean-Soil, Air, Water, vol. 40, no. 10, pp. 1145-1153, 2012.

[12] H. Horchani, I. Aissa, S. Ouertani, Z. Zarai, Y. Gargouri, and A. Sayari, "Staphylococcal lipases: biotechnological applications," Journal of Molecular Catalysis B: Enzymatic, vol. 76, pp. 125-132, 2012.
[13] H. K. Shon, D. Tian, D.-Y. Kwon, C.-S. Jin, T.-J. Lee, and W.-J. Chung, "Degradation of fat, oil, and grease (FOGs) by lipaseproducing bacterium Pseudomonas sp. strain D2D3," Journal of Microbiology and Biotechnology, vol. 12, no. 4, pp. 583-591, 2002.

[14] P. N. Ibegbulam-Njoku, O. K. Achi, and C. C. Chijioke-Osuji, "Use of palm oil mill effluent as fermentative medium by lipase producing," International Journal of Scientific \& Engineering Research, vol. 5, no. 2, 2014.

[15] W. Yeoung-Sheng, H. Shu-Huei, L. Chang-Hung, and H. JaoJia, "Adsorption of complex pollutants from aqueous solutions by nanocomposite materials," Clean-Soil, Air, Water, vol. 41, no. 6, pp. 574-580, 2013.

[16] APHA, American Public Health Association Standard Methods for the Examination of Water and Wastewater, APHA, New York, NY, USA, 22nd edition, 2012.

[17] R. Gupta, N. Gupta, and P. Rathi, "Bacterial lipases: an overview of production, purification and biochemical properties," Applied Microbiology and Biotechnology, vol. 64, no. 6, pp. 763-781, 2004.

[18] L. Bora and M. C. Kalita, "Production and optimization of thermostable lipase from a thermophilic Bacillussp. LBN4," The Internet Journal of Microbiology, vol. 4, no. 1, 2007, http://www.ispub.com/journal/the-internet-journal-of-microbiology/volume-4-number-1/production-and-optimization-ofthermostable-lipase-from-a-thermophilic-Bacillus-sp-lbn-4 .html\#sthash.qRHstqSc.dpbs.

[19] S. Bradoo, R. K. Saxena, and R. Gupta, "Two acidothermotolerant lipases from new variants of Bacillus spp," World Journal of Microbiology and Biotechnology, vol. 15, no. 1, pp. 97-102, 1999.

[20] S. S. -Dash, R. Subramani, and D. S. Kompala, A Method for Rapid Treatment of Wastewater and a Composition Thereof, World Intellectual Property Organization (WIPO), Geneva, Switzerland, 2011. 

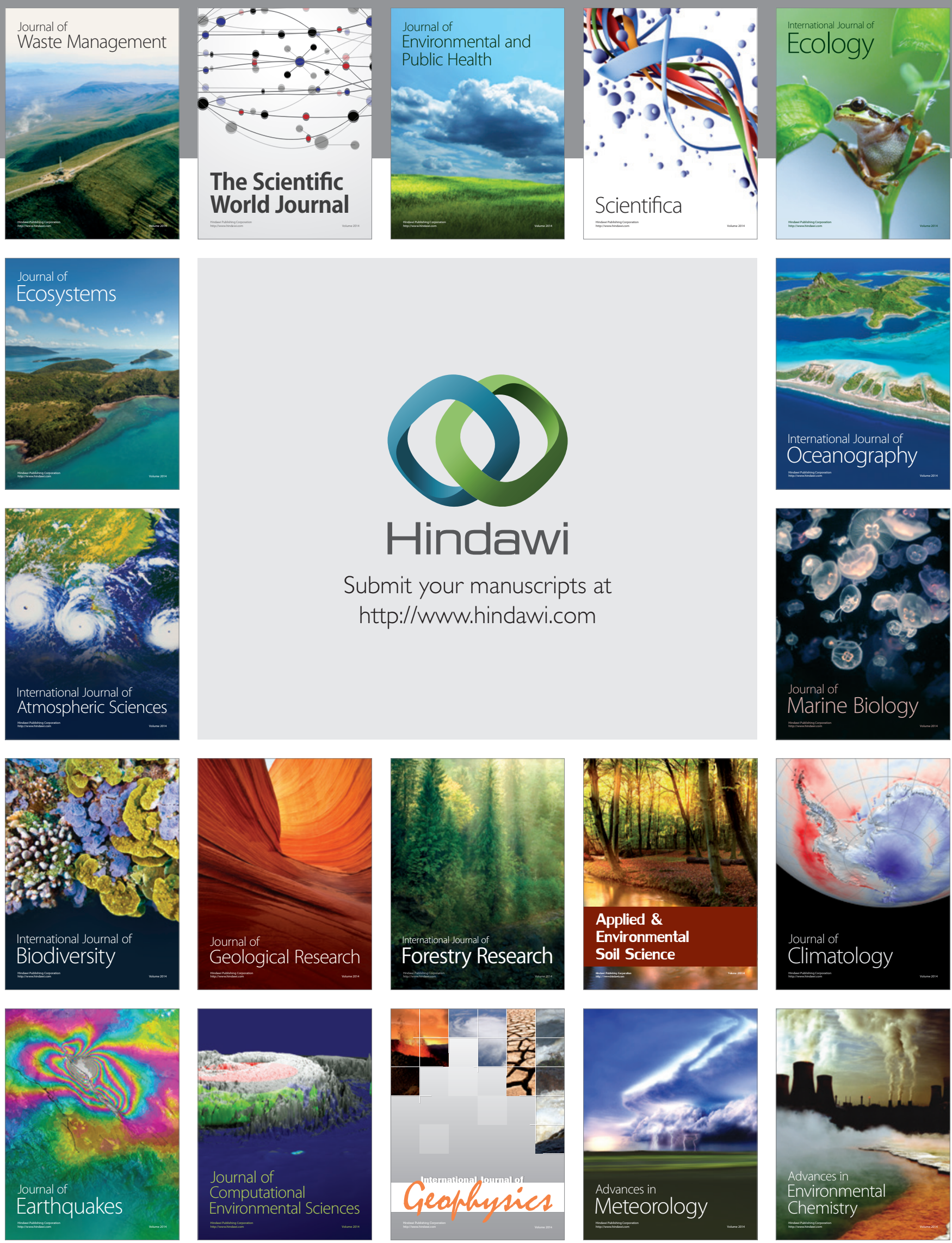